UNIVERSITY OF CHITRAL JOURNAL OF LINGUISTICS AND LITERATURE

VOL. 1 | ISSUE I | JULY - DEC | 2017

ISSN (E): 2663-1512, ISSN (P): 2617-3611

\title{
Genderlect Styles: Analysis Of Ibsen's “A Doll's House” From The Perspective Of Gender Differences In Language Use
}

\author{
Robina Khaliq \\ Lecturer in English, National University of Modern Languages (NUML) \\ Peshawar Campus Pakistan \\ robeenakhaliq@gmail.com \\ Mehnaz \\ Lecturer in English, National University of Modern Languages (NUML) \\ Peshawar Campus Pakistan \\ mehkhan@numl.edu.pk
}

\begin{abstract}
This present paper examines Ibsen's A Doll's House from the viewpoint of gender differences in the use of language by the characters in the play, and the way the lives of the characters are affected by the use of language. The study concludes that the prevalent ideologies in the society define the gender roles that stimulate women to maintain intimacy and connection and men to preserve their independence and status. However, females break this connection when they tend to preserve their identity and individuality instead of maintaining connection. The analysis of the selected text, from the play, is carried out through using Discourse analysis tools like Identity Building Tool, Turn Taking and Holding Floor, Story Telling, Empty Adjectives, Intensifiers. Tannen's theory of Genderlect Styles and Althusser's concept of Ideological State Apparatuses have been used to draw the conclusion.
\end{abstract}

Key Words: Discourse Analysis, A Doll's House, Genderlect Styles, Ideological State Apparatuses.

\section{Introduction}

Ibsen's A Doll's House has received multiple approaches. (Finch; 2011, Aulakh; Baseer et.al, 2013 , 2015) concentrating on feminism, the rights and liberation of women. Yet the notion that nobody is suppressed in the course of the play; rather every individual (male/female) speaks from his/her respective standpoints corresponding to his/her subcultures as pointed out by Deborah Tannen (1990). Tannen in her book You Just Don't Understand: Women and Men in Conversation (1990) theorizes that males and females speak dissimilar dialects thus establishes Genderlect Theory. The objective of Genderlect theory is to discover how men and women talk idiosyncratically which results into miscommunication.

\section{Literature Review}

Males' and females' use of language has been the point of discussion since long (J.L Viveswrote, 1538; Bingham, 1785). Otto Jespersen (1922) presented the notion of women's speech being deficient in his book Language: Its Nature and Development. However, this idea remained 
unobserved until Lakoff (1975) brought forth the concept of "Women's Register", contending that females' language use show their subservient role. This viewpoint has been marked as "deficit approach" which prompted various research studies in the field of gender discourse showing that the communication patterns of men and women reflect the superiority of men in society, thus proposing the " dominance approach". Yet, the 'sub-culture' theorists Maltz and Broker (1982) and Tannen (1990) believed that the language use by women was "different", not "deficit" or subsidiary, hence presented the" difference approach".

Discourse has been defined as text beyond the level of sentence or the linguistic realization of an individual's social interest. Discourse analysis provides a framework to evaluate language patterns in use (Gee, 1999, Jhonstone, 2008). Hence, tools from discourse analysis are applied to identify gender differences in language use. (Brown 1980; Goodwin 1980; Fishman 1980; West and Zimmerman 1975 Tannen 1990).

The discourse analysts take samples of the language used by men and women for study. Tannen (1990) is among one of the scholars who examined routine conversations. She contended that men and women's manner of speaking is dissimilar both in function and in nature. Tannen (1990) regarded males and females' language to be "two distinct dialects" which were neither inferior nor superior to each other. Tannen's theory established the "difference approach' in language use (according to which male- female conversation is 'cross cultural'), in gendered discourse.

A Doll's House (1889) has received multiple interpretations. A. Finch (2011) talks about the significance of the play with regard to the rights of women and the restrictions of the society in general. He places this very play in post-feminist and evolutionist context. Aulakh (2015) analyzed the gendered linguistic variation in A Doll's House and Hedda Gabler and concluded that males' speech shows dominance while females' speech was marked by hesitancy.

Yet the idea that in the course of the play nobody is suppressed rather the individuals (male and female) speak from their own standpoint and in accordance with their own subcultures as pointed out by Deborah Tannen (1990) is the key consideration of the present study.

\section{Theoretical framework}

The current study examines Ibsen's A Doll's House from the viewpoint of discourse analysis. The selected dialogues of the play are analyzed using discourse analysis tools yet applying Tannen's Genderlect Styles theory and Althusser's concept of Ideological State Apparatuses as the specific application to zero in on conversational exchanges among the characters.

\section{Data Analysis and Discussion}

As this work approaches the gender differences in the use of language by male and female characters in the play A Doll's House, the dialogues uttered by the characters have been selected and analyzed from the perspective that males and females, in the play, speak from their respective ideological positions and no one suppress anyone in the course of the play. 


\section{Questions}

The chief character Helmer asks rhetorical questions thus presenting himself as more dominant and assertive. For example;

Helmer:Is it the squirrel skipping about? P: 01

Helmer:"Bought," did you say? What all that? Has my little spend- thrift been making the money fly again? P:02

Helmer:What? Is the squirrel pouting there? (Takes out his purse) Nora, what do you think I've got here? P:02

Helmer: What do they calI the birds that are always making the money fly? P:03

The above mentioned dialogues evidently show that Helmer uses this specific strategy to affirm his "Status" as someone is in command and who possess more awareness and understanding of the world.

Rhetorical questions do not function like regular questions in discourse, rather they express a view which may be confirmed and agreed by the discourse participant. Helmer's use of rhetorical questions shows his Status as a man. Furthermore, Helmer asks critical questions to sustain his position and prove himself to be more knowledgeable as it is shown in the dialogues uttered by him. On the other hand, Nora asks tag questions which are usually for confirmation and for keeping the conversation carrying on as illustrated below;

Nora: Aren't you frozen?

NORA. Yes; isn't it? (Ibsen, 1879, P.8)

The tag questions by Nora indicates her as a person who has less knowledge therefore whatever she says is to be confirmed by her listener. Additionally, she attempts to retain the conversation cycle, thus creating and maintaining connectivity. According to Tannen (1994), men do not ask questions for confirmation or for getting help as doing so will depict their ignorance thus preserving their public face. The analysis of the selected dialogues shows that Helmer does not ask questions for confirmation or information; rather he is constantly there to guide Nora.

\section{Identity Building Tool}

A number of strategies have been used by the characters to build identities for themselves and others who interact with them. For example, Naming, use of possessives and framing.

\section{i. Use of Naming and Possessives}

Throughout the play Helmer uses names like "Lark" (P.6) "Squirrel”, "Songbird (p.7) to address her. Helmer's handling of his wife Nora shows her to be a feeble and small child who is entirely at his mercy. The use of Possessive "My" with each label he ascribes to his wife, she is objectified as a being who is owned by him and who can be controlled within the little sphere of home.

Helmer uses these names as terms of endearments because his position as a man motivates him to call her by such names hence to establish his "Status" at home. By calling her "Lark", "Squirrel" or "Songird", he does not dehumanize his wife; rather his linguistic choices are the result of his role and position. In the same way, by constantly calling her as, "my capricious little girl" (P.95) 
"little one", "little girl," and "my willful little woman" (P.45) he does not try to create an atmosphere of subordination but maintains his position as a man.

According to Mcconnell-Ginet Social labeling practices offer a window on the construction of the gender identities and social relations. Thus, Helmers practice of labeling Nora, constructs his identity as well as Nora's identity of a totally dependent woman which was typical of the then time women.

Helmer builds his identity as an independent man who is very much conscious about what others in society think and speak about him.

The dialogues show this very concern when Nora requests him to keep Krogstad's positions in the bank where the newly appointed manager refuses to do so.

HELMER. Oh, nothing, so long as a willful woman can have her way-! I am to make myself a laughing-stock to the whole staff, and set people saying that I am open to all sorts of outside influence? (P.59)

It seems quite impossible for Helmer to expose any sort of non-individuality and dependence. He does not want to let it known to people that he can be influenced by his wife or any other person; rather he acts on his own without taking into account his wife's opinion or desire, thus preserving his individuality and independence.

Nora, on the other hand, tries to convince him to keep his post in the bank because if Krogstad is dismissed, he would let Helmer know about the forgery Nora has done in order to get money for Helmer's treatment. Nora's effort shows that she is concerned with her family and her happy relation with Hemler which will be shattered if Helmer comes to know about her deed.

When Helmer asks her not to spend more money, she replies: Nora: Very well-as you please, Torvald. To keep her family and connection with Helmer intact, she again requests him as indicated in the dialogues.

Tannen (1990) states that a woman views intimacy as a key to achieve harmony and avoids presenting an air of superiority because she sees the world as a set of connections. Nora's efforts to keep her act of forgery secret are motivated by this very notion and for this reason she begged her husband to keep Krogstad in the bank.

\section{ii. Framing}

Goffman (1982) considers framing as, "the alignment we take up to ourselves and the others present as expressed in the way we manage the production or reception of an utterance. A change in our footing is another way of talking about a change in our frame for events..."(pp. 128) Throughout the play Helmer frames Nora as a child and unreasonable being. The dialogues when Nora says that they will borrow money till Helmer takes his salary, are indicative of the way

Helmer frames Nora. 
Helmer. Yes, from New Year's Day. But

there's a whole quarter before my first salary

is due.

NORA. Never mind; we can borrow in the meantime.

Helmer: Nora! Thoughtless as ever! (P.3)

Both Nora and Helmer act in their respective frames in order to make the identity they want to construct for themselves and for others.

He advises Nora for not taking any debts thus establishing his identity as a reasonable person. It also gives a metamessage to Nora that she does not take wise decisions and framing her as unreasonable lady. The utterance, "you know my principles on these points"(P.4), shows that he has an upper hand at home and Nora abides by his principles that he has devised.

Nora maintains her identity as a caretaker of home and family considering Helmer's position as breadwinner. Moreover, the dialogues where Helmer confirms from Nora that she has not been eating any sweets also show the frame he is in and the frame he has put Nora into. Instead of asking one time question of either she has eaten the sweets is repeated by Helmer many times in different words like:

"Didn't she just look in at the confectioner's? “,"Not to sip a little jelly?" And "Hasn't she even nibbled a macaroon or two?" $(1879, \mathrm{p} .3)$

According to (Norrick 2000/2001) repetition is used for emphasis and a state of reference for the speakers. The type of repetition used by Helmer is termed as Commoratio which is defined by Marriam Joseph (1947) in "Shakespeare's Use of the Arts of Language" as "a figure whereby one seeks to win an argument by continually coming back to one's strongest point...".

Helmer's use of Commoratio is a tool for proving himself one in command of Nora even in the case of eating something.

Nora has accepted her role as a child and dependent one because she feels loved and cared by receiving such treatment by her husband. For example:

NORA. If your little squirrel were to beg you for something so

NORA. The squirrel would skip about and play all sorts of tricks if you would only be nice and kind. (1879, P:22)

Nora accepts labels like "lark" as term of endearments from her husband at this moment. She does not challenge him by calling her a "Lark" rather by saying "yes, it is" instead of "Here I am", she approves this as gesture of love and care. In the same way, when she requests Helmer to keep Krogstad in the bank, she explicitly takes part in her objectification. She frames herself as someone who relies on him in most of her life's decisions. This gives an indication that Nora has accepted her role as a dependent being. The lines show that Helmer does not frames Nora as a dependent lady who is always in need of help and security from him on the purpose of belittling or dehumanizing her. Rather, his ideological position as a man motivates him to play the role of a powerful person whose duty is to secure and protect his home and family. The identity Helmer 
UNIVERSITY OF CHITRAL JOURNAL OF LINGUISTICS AND LITERATURE

builds for himself also plays a role in the identity building of Nora. However, the identity Helmer builds for himself, is an attempt to preserve his "status" as a man as indicated in his dialogues:

Do you know, Nora, I often wish some danger might threaten you, that I might risk body and soul, and everything, everything, for your dear sake. (1879, P:39)

Only lean on me; I will counsel you, and guide you. I should be no true man if this very womanly helplessness did not make you doubly dear in my eyes. (1879, P:41)

You may rest secure. I have broad wings to shield you. (1879, P:41)

Similarly, the identity he constructs for Nora is not aimed at demolishing her rights, which is indicated in the following lines:

HELMER: "Well, we will share it, Nora, as man and wife should. That is how it shall be."

The utterance shows that Torvald is quite aware of the notion of marriage being a shared experience where both man and woman are equal partners and no one suppresses the other one.

\section{iii. Shift in Footing}

According to Goffman (1982), "Change in footing is very commonly language linked; if not that, then at least one can claim that the paralinguistic markers of language will figure."( $(\mathrm{P}, 128)$.

A change in footing by Nora is observed at the end of the play. Throughout the play, Helmer holds the floor for longer and talks more, but at the end of the play, Nora holds the floor and talks more. Nora changes her dress, and by wearing a plain black dress and the way she talks to Helmer symbolically represents her new self. The use of directives like:

"Don't interrupt. Only listen to what I say...." and

"Sit down, Torvald" (1879, P.112) indicate that she tries to acknowledge her identity as an independent person. Nora has realized that she should discover and establish her own identity first and then she can become a better wife and mother. She leaves her home and family to show that her soul is awakened and now she is determined to become an individual person which would not be treated like a doll by any men. She tries to escape situation which she regards an oppressive one and which does not let her grow as an independent individual. She thinks that her father and husband have done "wrong" to her by treating her as a child. Her opinions, according to her, were formed by her father. The words "your house" shows that she does not own the house she has been living for years. She challenges the frame she has been living in.

\section{Turn Taking and Holding Floor}

Turn taking is regarded as cyclic procedure by Newell, Arnott, Woodburn and Procter (2011), with one person continues talking until he gives turn to the other person in conversation and the conversational floor is held by the second speaker until the talk is finished and the control goes back to the first speaker.

According to Coates (1996) holding the floor refers to the fact when a speaker speaks for a long period of time. The conversational exchanges between Nora and Helmer indicate the extent of turn taking and holding the floor by Nora and Helmer. The dialogues between Helmer and Nora show 
UNIVERSITY OF CHITRAL JOURNAL OF LINGUISTICS AND LITERATURE

that Helmer holds the floor for longer period of time while Nora's responses are short and she mostly asks questions for clarification of what is already said by her husband which is an indication to him to take over the turn.

NORA. Yes, Torvald; but-

HELMER. Nora, Nora! And you could condescend to that! To speak to such a man, to make him a promise! And then to tell me an untruth about it!

NORA. An untruth!

HELMER. Didn't you say that nobody had been here? [Threatens with his finger.] My little bird must never do that again! A song-bird must sing clear and true; no false notes. [Puts his arm round her.] That's so, isn't it? Yes, I was sure of it. [Lets her go] And now we'll say no more about it. [Sits down before the fire.] Oh, how cosy and quiet it is here! [Glances into his documents.] (1879, P. 17) NORA.

Do you think that-?

HELMER. Just think how a man with a thing of that sort on his must be always lying and canting and shamming. Think of the mask he must wear even towards those who stand nearest him-towards his own wife and children. The effect on the children-that's the most terrible part of it, Nora.( 1879,P.44)

Tannen (1990) states that men's conversation is mainly focused on lecturing, that is to say they are mostly centered on advising or giving directions. Kotthoff (1997) finds out that by using lecturing which suspends turn taking, asserting an arguable claim in a straightforward way men gain a high intrinsic status. She further argues that women tend to listen and agree to what men say to establish and maintain connection while men misinterpret this agreement as the reflection of their power and status. As a result of listening and acknowledgement on women's part, men might conclude that women are insecure and indecisive. But the reason for behaving this way by woman is the result of her attitude towards the relationship she is in and it has nothing to do with her agreement of men's power and status.

Giving information and holding the floor for long frames the speaker with a high status, on the other hand listening and agreement frames the listener as someone lower in status. While listening to men, women do not think about status, rather they think in terms of support and connection.

\section{Story Telling}

Stories have concurrent functions: that is to please, instruct, praise others or to establish connection. (Labove, 1972, Heath 1982,Riessman 1993, Schiffrin 1994). In the play the female characters (Nora and Mrs. Lindi) tell their life stories to each other.

"MRS. LINDEN. You spent a whole year in Italy, didn't you?

NORA. Yes, we did. It wasn't easy to manage, I can tell you. It was just after Ivar's birth. But of course we had to go. Oh, it was a wonderful, delicious journey! And it saved Torvald's life. But it cost a frightful lot of money, Christina.

MRS. LINDEN. Ah, I see. He died just about that time, didn't he? 
UNIVERSITY OF CHITRAL JOURNAL OF LINGUISTICS AND LITERATURE

NORA. Yes, Christina, just then. And only think! I couldn't go and nurse him! I was expecting little Ivar's birth daily; and then I had my poor sick Torvald to attend to. Dear, kind old father! I never saw him again, Christina. Oh! that's the hardest thing I have had to bear since my marriage. (1879, P.5)

Nora: .........Now tell me, is it really true that you didn't love your husband?( 1879, P.6) MRS. LINDEN. My mother was still alive... Papa died at that very time. I meant to have told him all about it, and begged him to say nothing. But he was so

ill-unhappily, it wasn't necessary.” (1879, P.8)

Coates (1996) believes storytelling to be as important aspect in women's lives as stories serve the purpose of making and maintaining connection among them. Narrating stories to friends prove to be a strong component of 'doing friendship'. She further argues that while telling stories, the focus is either on discussing worries or the events that went smoothly. Likewise, the storyteller is either the victim of a situation or in charge of it. Stories telling construct a particular identity.

In the play, Nora constructs her identity that of a responsible lady. Although the way she chose for getting money to treat her husband was wrong but that was the only possible way for getting money at that time. Even though she knew that Krogstad writes for the most 'scurrilous paper', still she asked him to forge her father's signature and then in order to repay the money, she worked hard to earn money which proves her to be a self-sacrificing woman.

Similarly, Mrs. Lindi also created the identity of a self-sacrificing woman who even lost her love for the well-being of her family and married a man who was older than her because she needed money for her young brothers and for the treatment of her mother. Money had been the mutual problem of the two women. Had Nora not been a self-sacrificing woman she would not have been chosen the wrong way and putting her honor at stake for her husband's sake. Similarly, if Mrs. Lindi had not been a lady with fine heart, she would not have left her love.

\section{Empty Adjectives}

Lakoff (1973) contends that empty adjectives like wonderful, lovely, divine are generally used by females in conversation. In the present play, many empty adjectives are being used by the female characters. Some of the dialogues are selected as example.

NORA. Oh, isn't it wonderful? (1879 P.4)

Nora.Oh, how delightful! (1879 P.4)

Mrs Linden.. Yes; at any rate it must be delightful to have what you

need. (1879, P.5)

Nora: And yet it was splendid to work in that way and earn money. (1879, P.9)

The adjectives like wonderful, glorious, lovely, splendid, poor, delightful, tremendous, beautiful, delicious, are recurrently used by the female characters in their conversation.

Lakoff (1975) classifies a set of adjectives as empty adjectives as they are used to express approval and admiration. The use of empty adjectives is specific to female speech as the use of this group of adjectives by men may risk the reputation of men as someone who is holding a status. 


\section{Intensifiers}

Female speech is marked by the use of intensifiers in the play. Some examples are in the dialogues: MRS. LINDEN. And much, much older, Nora. (1879,P.4) Nora :Oh, sometimes I was so tired, so tired. (1879, P.9) MRS. LINDEN. Yes; I go so very slowly. $(1879, \mathrm{P}, 10)$

NORA. Oh, it's too tiresome. (1879, P.17)

Intensifiers are used by females to emphasize to what they say. Lakoff (1975) asserts that women use intensifiers with the purpose of persuading the addressee to take their talk seriously and also to enhance the strength of their statement because they consider their utterance to be unheeded. In other words, Lakoff suggests that women's use of intensifiers indicate their lack of confidence.

\section{Conclusion}

The analysis is primarily focused on analyzing the use of language by both male and female characters. Women's talk is marked by self-disclosure that leads to build and maintain intimacy and relationship. While men talk is aimed at building and maintaining their status, preserving independence and less self-disclosure.

The data analysis shows that Nora's impression about her treatment by her father and husband is because of the gender differences in language use. The application of Tannen's(1990) theory of "Genderlect Styles" to the present play, indicates that men's and women's use of language is aimed at different ends. For example, the male characters in the play are concerned with their 'status' and 'independence' while the females maintain 'connection' and 'intimacy'. Women (e.g Nora) avoid conflicting situation because it is a threat to connection and intimacy. The last scene of the play presents a striking difference in the situation when Helmer comes to know that Nora has loaned money from the bank without his permission.

By using the 'Footing' tool, the last scene is analyzed to see how the footing of the main character is changed. Nora decides to leave her family as she thinks that she has not been treated well by her husband. Nora leaves her house and family because of the misunderstanding caused by the language differences.

This language differences are based upon their role in the society. Males are ideologically prompted to use the language in such a way as to preserve their status and maintain their independent role. Females, on the hand, are ideologically stationed in a position from where they are motivated to use their language in such a way as to preserve connection and maintain intimacy. The differences in language use motivate disconnection at the end of the play between Nora and Helmer. By deciding to leave her family behind, Nora's challenge is threefold; i.e challenges the existing order of the society and the ideological standing of her husband and secondly she questions her own existence and ideological position, thirdly she challenges the institutions and the rules these institutions have for every individual in society. Her declaration to educate herself is a decision to the authenticity of the norms and rules she has been following all her life. She challenges the norms and the prevalent ideology of the society about the role of a woman. 
By leaving her family she does not seek freedom for the role of a wife and a mother rather she seeks to establish her identity as individual. She leaves her family because she realized that establishing an individual identity for herself is more essential 'duty' to her than any other duty. The difference in the language use gives a way to disconnection, a point which Tannen misses out in her theory. Tannen's notion of women being seeking connection and intimacy is modified through the present study. If a woman becomes aware of her duties towards herself and develop a sense of individuality, many cases of disconnection can be observed because she would be breaking the norms of the society for the establishment of her individuality.

According to Althusser 1975, Ideological State Apparatuses (ISAs) which include education, religion, family, communication, culture, the legal system education to unite the society through ideology and produce a system by manufacturing the agreement. Culture and education as ISA, instructs the individuals in society to act in a certain way that is desirable to their roles. The ideology is carries by 'concrete' individuals who agree "always-already interpellated" as subjects. The subjects so not act as an independent powerful agent with self- created identities rather the individuality and social identity of a subject are produced by social forces. Thus, both the male female characters in the play are controlled by the prevalent ideologies of the culture and society. Helmer does not see Nora as a child who is subordinate to him and who lacks the ability to understand serious matters. His use of terms of endearment like "skylark" or "songbird" for Nora and advising her about spending money are to build and maintain his status and independence as a male because he is required to preserve his identity as a man as he has got the label of a man. According to Althusser's Ideological state apparatuses, Helmer's ideological position as a man compels him to act in this way. Helmer being the product of his culture, cannot help the situation as the society does not allow a female to do anything significant like business dealings without the husband's approval. Women were confined to household chores only. But it does not mean that the women suppressed by men, rather being confined to the norms of society, men were also confined.

Society as ISA, has defined a specific pattern of behavior for both Nora and Helmer as per their status i.e. husband and wife hence, the language used by both of them is inspired by their roles where Helmer, being a man, tries to prove himself higher in intellect and reason than Nora and Nora, being a female, shows herself as naïve. The analysis shows that both males and females in the play are influenced by gender stereotyping, the society as ISA forces them to adhere to. Behavior patterns and attitudes are enforced on gender through stereotyping. Consequently, Helmer's use of language shows his stereotypical attitude of a man and an elder towards Nora and Nora's use of language presents her as a stereotypical woman who strictly adheres to her defined role. Thus, cultural norms play the role of ISA in society and for this reason all of the characters are directed by certain ideas.

\section{References}


UNIVERSITY OF CHITRAL JOURNAL OF LINGUISTICS AND LITERATURE

Finch A. (2011) A Post-feminist and Evolutionist Reading of A Dolls House. Retrievd from https://www.researchgate.net/publication/220025756 on 6th September 2015.

Althusser, L. (1968), Lenin and Philosophy and Other Essays, Monthly Review Press, New York. Aulakh K.J. (2015) Evaluation Of Gendered Linguistic Variations In Henrik Ibsen's A Doll's House And Hedda Gabler. Published In The International Journal Of Humanities \& Social Studies (ISSN 2321 - 9203).

Baseer, Alvi, Zafran (2013), The Use of Symbolic Language in Ibsen's A Doll's House: A Feministic Perspective. Published in Language in India www.languageinindia.com ISSN 1930-2940 Vol. 13:3 March 2013.

Coates.J. (1996). Women, Men and Everyday Talk, Palgrave Macmillan UK

Fishman, P. (1983) Interaction: the Work Women Do. University of California, Santa Barbara

Gee, J. P. (1999) An Introduction to Discourse Analysis Theory and Method. Routledge

Goffman. E. (1974) Frame Analysis: An Essay on the Organization of Experience. New York ; Harper and Row

Holmes. J (1995) Men, Women and Politeness. London, Longman.

Jespersen, O.(1922). Language: Its Nature and Development. Published by G. Allen \& bUnwinH. Holt, London New York ISBN 10: 0044000073

Jhonstone,2008) Discourse Analysis: An Introduction (Blackwell, 2001).

Kotthoff Helga (1997) "Communicating Gender in Context". Jhon Benjamins Publishing

Company Amesterdem/Philadelphia

Lakoff .R. (1973) Language and Woman's Place, Oxford University Press.

Lakoff, R. T. (1975). Language and woman's place. New York: Harper \& Row.

Maltz, D. N. and Borker, R. A. 1982 A cultural approach to male-female miscommunication. Language and Social Identity, in Gumperz (ed.), 196-216. New York: Cambridge University Press.

Spender, Dale. (1980). Man Made Language, London: Pandora Press.

Tannen, D. (1990). You just don't understand: Women and men in conversation. New York, Woodburn, R., Arnott, L., Newell, A.F., Procter, R. (2011): -A Study of Conversational TurnTaking in a Communication Aid For the Disable. Retrieved from citeseerx.ist.psu.edu/viewdoc/download?doi=10.1.1.50.1876\&rep=rep1...pdf on 6 October 2015

Zimmerman, D. And West, C (1975) 'Sex roles, interruptions and silences in conversation'. In Thorne, B. and Henley, N. (eds) (1975) Language and Sex: Difference and Dominance. Rowley: Newbury House.

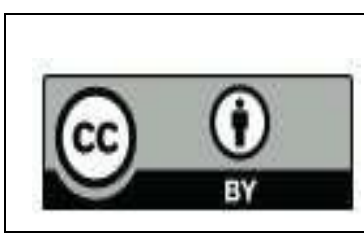

@ 2017 by the author. Licensee University of Chitral, Journal of Linguistics \& Literature, Pakistan. This article is an open access article distributed under the terms and conditions of the Creative Commons Attribution (CC BY) (http://creativecommons.org/licenses/by/4.0/). 
UNIVERSITY OF CHITRAL JOURNAL OF LINGUISTICS AND LITERATURE

VOL. 1 | ISSUE I | JULY - DEC | 2017

ISSN (E): 2663-1512, ISSN (P): 2617-3611

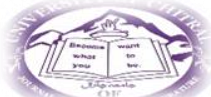

